\title{
PERENCANAAN SOSIAL DAN POLA KOMUNIKASI KOMISI PENANGGULANGAN AIDS (KPA) KOTA PADANG
}

\author{
Diego \\ Program Studi Ilmu Komunikasi, Universitas Dharma Andalas; dyandreas@gmail.com
}

\begin{abstract}
ABSTRAK
Sebagai salah satu kota yang berkembang, salah satu permasalahan urban yang tengah dihadapi oleh masyarakat kota Padang adalah tingginya angka penderita HIV/AIDS. KPA sebagai lembaga pemerintah di bawah Kementerian Kesahatan RI bertugas untuk melakukan sosialisasi dan perencanaan sosial menyangkut HIV/AIDS. Penelitian ini menggunakan metode kualitatif dengan melakukan wawancara dan observasi dengan anggota KPA dan konselor di HIV/AIDS di Kota Padang. KPA melakukan perencanaan sosial dengan memanfaatkan infrastruktur pemerintah berupa pelayanan tes VCT, konselor dan rumah sakit yang menyuplai obat-obat. KPA juga melakukan program prioritas dimana kelompok-kelompok yang rentang resiko penulsaran menjadi fokus untuk mencegah dan mensosialisasikan HIV/AIDS. Media yang digunakan untuk sosialisasi lebih dilakukan dengan pendekatan interpersonal, karena isu yang sensitif akan lebih mudah dijelaskan secara face to face.
\end{abstract}

Kata Kunci: Perencanaan Sosial, Pola Komunikasi, Komunikasi Kesehatan, HIV/AIDS, KPA Kota Padang

\begin{abstract}
As one of developing city, one of urban problems are now facing by its people is the high number people suffered from HIV/AIDS. KPA as governmental institution under the ministry of health is assigned to socialize the planning and program concerns to HIV/AIDS. This study used the qualitative method by interviewing and observing with members of KPA and its counselor in the city of Padang. KPA makes the social planning by utilizing VCT test, counselor and hospitals that supplies medicines. Kpa also sets priority program for high risk communities to HIV/AIDS by focussing on preventing and socializing HIV/AIDS. The media used to socialize done by making more interpersonal approach as sensitive issue will be more easily explained in a face to face way

Keywords : Social Planning, Communication Form, Health Communication, HIV/AIDS, KPA Kota Padang.
\end{abstract}




\section{PENDAHULUAN}

Kota Padang adalah ibu kota provinsi Sumatera Barat yang terletak di pesisisr barat pantai Sumatera. Sebagai ibu kota, Kota Padang adalah sentral perdagangan, pendidikan dan wisata dari berbagai kota sumatera. Aktivitas penduduk yang dinamis menjadi faktor penting dalam pembangunan, hal ini sejalan dengan apa yang dikemukakan oleh Jamaludin (2015:50) bahwa faktor non fisik memegang pengaruh penting dalam perkembangan sebuah kota. Kota Padang telah menjadi center of trade sehingga kota ini menjadi fasilitator pusat perdagangan dan niaga yang melayani daerah di sekitarnya. Penduduk Kota Padang sendiri berasal dari berbagai latar belakang suku, tingkat pendidikan, agama, tingkat pendapatan dan lain sebagainya membuat kota ini mengalami perkembangan yang pesat di berbagai bidang dan juga disertai berbagai permasalahan yang ditimbulkan.

Namun, pesatnya pertumbuhan dan keterbukaan sebuah kota juga memunculkan masalah baru untuk Kota Padang. Salah satu permasalahan yang tengah dihadapi oleh masyarakat kota Padang adalah tingginya angka penderita HIV/AIDS di Kota Padang. Data kesehatan di Sumatera Barat menunjukkan penduduk Sumatera Barat yang terinfeksi HIV/AIDS dari tahun ke tahun terus meningkat. Provinsi Sumatera Barat sendiri menempati peringkat ke delapan dalam rate kumulatif penderita HIV/AIDS di Indonesia. Data dari Kemenkes ${ }^{1} 2017$ mendapatkan angka kenaikan pendertita HIV/ AIDS di Sumatera Barat setiap tahunnya. Pada tahun 2015 ada 1272 penderita HIV/AIDS, pada tahun 2016 angka tersebut bertambah menjadi 1515 penderita dan di tahun 2017 terdapat 1214 penderita HIV/AIDS di Sumatera Barat. Angka tersebut membuat masyarakat merasa khawatir mengingat penderita yang tertular HIV/AIDS itu sendiri pada awalnya tidak memiliki ciri-ciri spesifik dan hanya bisa terdeteksi dengan melakukan tes darah. Kota Padang sendiri tidak luput dari peningkatan jumlah penderita virus itu sendiri secara spesifik. Data dari BPS (2016) menyebutkan bahwa jumlah penderita HIV/AIDS di kota Padang terbanyak terdapat di kecamatan Padang Selatan, yaitu 41 penderita $^{2}$

Fenomena ini seperti gunung es, data yang didapatkan di lapangan hanya menjelaskan sebagian data real. Salah satu yang membuat penderita suspect HIV/ AIDS tidak melaporkan kasusunya, karena masih ada stigma negative terhadap penderita HIV/AIDS. Pemerintah sendiri dalam hal ini Komisi Penanggulangan AIDS sudah melakukan berbagai cara untuk mengurangi stigma dan diskriminasi di masyarakat. Salah satunya KPA melakukan penyebaran sosialisasi agar masyarakat lebih paham mengenai penyakit HIV/AIDS.

Pada konteks penanggulangan HIV/AIDS perencanaan sosial adalah kegiatan untuk mempersiapkan masa depan masyarakat. Pesatnya penyebaran HIV/AIDS bukan hanya mengancam demografis penduduk namun juga harus menanggung biaya besar penderita HIV/AIDS.Hal ini tentu saja menjadi beban pemerintah, karena suplai obat dan perawatan pasien HIV/AIDS menjadi tanggung jawab pemerintah.Sampai dengan tahun 2016 saja, terdapat 557 penderita AIDS di kota Padang, tentu saja angka tersebut merupakan hasil yang menakutkan mengingat angka 557 adalah yang terdeteksi saja,

\footnotetext{
${ }^{1}$ http://siha.depkes.go.id/portal/files_upload/Laporan_HIV_AIDS_TW_1_2017_rev.pdf

${ }^{2}$ https://padangkota.bps.go.id/dynamictable/2017/07/07/91/jumlah-kasus-hiv-aids-ims-dbd-dia re-tbdan-malaria-menurut-kecamatan-di-kota-padang-2016-.html
} 
sedangkan masyarakat yang belum terdeteksi jauh lebih besar dibandingkan angka yang tertera. Perkembangan yang mengkhawatirkan juga disusul oleh kota Bukittinggi, sebagai kota pariwisata angka 214 penderita bisa dikategorikan sangat tinggi mengingat kota ini adalah kota kecil. Kasus penularan masyarakat terjangkit virus HIV \& AIDS sangat mengkhawatirkan karena penularan serta wilayah penyebarannya semakin meluas. Trend jumlah kasus baru HIV \& AIDS di kota ini dari tahun ke tahun mengalami peningkatan. Sejak tahun 2007 sampai akhir 2013 saja, tampak bahwa setiap tahunnya telah terjadi peningkatan kasus baru lebih dari 100 orang. Perencanaan sosial yang baik tentu harus dikomunikasi melalui media atau komunikasi interpersonal kepada masyarakat. Dengan melakukan pemilihan media yang tepat, maka program pemerintah bisa tersosialisasikan dengan baik. Masyarakat pun diharapkan mempunyai kesadaran dan pengetahuan yang cukup tentang HIV/AIDS.

Berdasarkan permasalahan di atas maka tulisan ini akan melihat bagaimana perencaan sosial yang dibuat oleh KPA Kota Padang dan bagaimana pola komunikasi agar program perencanaan tersebut bisa diketahui oleh masyarakat.

\section{Perencanaan Sosial}

Istilah perencanaan sosial yang mula digunakan di negara maju seperti Eropa Barat dan Amerika Utara, pada dasarnya mempunyai kaitan yang kuat dengan perencanaan perundang-undangan tentang pelayanan kesejahteraan sosial. Rangkaian kegiatan ini dibentuk guna memungkinkan individu, keluarga, kelompok masyarakat untuk mengatasi masalah-masalah sosial dikarenakan adanya perubahan keadaan.

Pengertian kesejahteraan sosial mencakup suatu daftar kegiatan pelayanan khusus yang telah dicantumkan dalam suatu terbitan PBB mengenai pelayanan kesejahteraan sosial tahun 1959. Daftar kegiatan tersebut yaitu : bimbingan keluarga, pendidikan orang tua, pelayanan perawatan sehari-hari, pelayanan kesejahteraan anak, perawatan orang lanjut usia, rehabilitasi para cacat dan napi, pelayanan bagi pengembara dan pengungsi, kegiatan kelompok remaja, pelayanan kesejahteraan dan pengobatan, kegiatan persekolahan, pusat pelayanan sosial yang ada kaitannya dengan masalah perumahan.

(Walker, 1983) membagi perencanan sosial dalan dua kategori. Kategori yang pertama perencanaan sosial adalah sebagai penggerak perubahan dan pencapaian pembangunan sosial, pada kategori ini melihat pemberdayaan masyarakat untuk terlibat aktif dalam pembangunan. (Diana Conyers, 1983). (D Conyers \& ., 1991) menegaskan perencanaan sosial adalah sebagai cara untuk mencapai keadilan sosial. Pada kategori kedua Walker menempatkan perencanaan sosial sebagai bagian dari sistem kesejahteraan sosial yang berlaku pada masyarakat kapitalis, pada konteks ini para ahli melihat hubungan antara tiga unsur dalam masyarakat yakni pemerintah sebagai pengelola daya, swasta dan masyakarat sebagai penyumbang pajak dan dana dan terakhir adalah klien sebagai penerima bantuan sosial (Glennester, 1975).

Perencanaan sosial dimaksudkan agar mampu menterjemahkan kebijaksanaankebijaknsanaan pemerintah dalam bentuk program-program khusus atau bentuk-bentuk peraturan bagi semua jenis pelayanan, termasuk pelayanan yang membantu individu dan kelompok yang hidup berkekurangan. Perencanaan sosial dipandang sebagai dua jenis gambaran masyarakat Barat. Yang pertama perencanaan sosial menggambarkan adanya 
peran yang cukup penting bagi negara dalam pengadaan pelayanan masyarakat. Yang kedua, dirasakan sekali timbulnya kenyataan bahwa negara maju seperti Eropa Barat dan Amerika Serikat tidak menjalankan perancaan pembangunan secara normal dalam artian perencanaan sosial tersebut sebagaimana ada dalam penjelasan terdahulu.

Timbulnya perencanaan sosial di dunia ke tiga sepuluh tahun terakhir ini bukan sematamata sebagai suatu pertanda akan naiknya tingkat kebutuhan pelayanan kesejahteraan sosial, tetapi menyangkut penggeseran ruang lingkup yang lebih luas dari perencanaan pembangunan yang dengan lebih memberi tekanan pada perubahan sosial dan pencapaian tujuan sosial itu sendiri.

Dipertimbangkannya perubahan struktur sosial merupakan pendekatan yang sangat penting dalam kebijaksanaan sosial dan perencanaan sosial. Conyers mengasumsikan bahwa para perencana sosial selalu dihubungkan dengan pencapaian sosial dengan mengaitkan antara masalah sosial, kebijaksanaan sosial serta perubahan struktur sosial. Dalam hal ini Conyers mengimplikasikan kebijaksanaan alternatif dan dampak dari bentuk rencana yang akan mengarah kepada keadilan sosial dan perubahan sosial

\section{Pola Komunikasi}

Pola komunikasi adalah aktivitas komunikasi menyampaikan pesan dan kemudian mendapatkan feedback dari penerima pesan. Penyampaian pesan komunikasi bisa dilakukan menggunakan alat atau media, dalam hal ini bisa berupa pamphlet, poster, spanduk atau iklan di media. Pola komunikasi bisa dikategorikan pola komunikasi linear, dimana penyampaian pesan dari komunikator kepada kepada komunikan dilakukan melalui satu arah antara komunikatir kepada komunikan, sedangkan pola komunikasi sirkular terjadi ketika adanya umpan balik oleh komunikator, proses ini dimungkinkan ketika komunikasi dilakukan face to face. Pada proses ini, pola komunikasi dengan adanya feebback, maka proses komunikasi akan berlangsung terus (Komariah, K., Perbawasari, S., Nugraha, A. R., \& Budiana, H. R., 2013).

Pada konteks ini KPA Kota Padang melakukan komunikasi kesehatan yakni menyebar luaskan informasi kesehatan agar bisa mempengaruhi dan memotivasi individu agar bisa mendapatkan kesehatan yang lebih baik. Komunikasi kesehatan meliputi informasi tentang pencegahan penyakit, promosi kesehatan, kebijaksanaan pemeliharaan kesehatan, regulasi bisnis dalam bidang kesehatan, yang sejauh mungkin mengubah dan membaharui kualitas individu dalam suatu komunikasi atau masyarakat dengan mempertimbangkan aspek ilmu pengetahuan dan etika (Liliweri, 2007: 47).

\section{Komunikasi Kesehatan}

Komunikasi kesehatan adalah proses untuk mengembangkan atau membagi pesan kesehatan kepada audiens tertentu dengan maksud memengaruhi pengetahuan, sikap, keyakinan mereka tentang pilihan perilaku hidup sehat. Studi mengenai komunikasi kesehatan pada dasarnya menghubungkan studi komunikasi dengan kesehatan. Dalam artian itu maka studi tentang kesehatan masyarakat "ditambahkan" satu tema penting yakni peranan komunikasi, terutama strategi komunikasi dalam merancang dan menyebarluaskan informasi kepada individu, keluarga, komunitas, orgnisasi maupun masyarakat umum sehingga semua kelompok dapat membuat keputusan yang tepat terhadap usaha pemeliharaan kesehatan. 


\section{METODOLOGI}

Metode penelitian yang digunakan adalah pendekatan kualitatif, hal ini dilakukan karena peneliti ingin meneliti perencanaan sosial dan pola komunikasi kesehatan KPA Kota Padang dalam menjangkau masyarakat. Perencanaan sosial dan pola komunikasi yang baik dapat diperoleh dengan metode penelitian kualitatif karena peneliti harus memperoleh data secara mendalam dari informan-informan yang ada dengan acuan studi literatur, wawancara dan observasi yang peneliti miliki.

Paradigma yang digunakan dalam penelitian ini adalah konstruktivisme. Paradigma ini masuk dan memahami perencanaan komunikasi kesehatan yang baik agar konselor dapat menjangkau masyarakat yang beresiko tertular. Masyarakat bertindak sebagai agen yang mengkonstruksi dalam realitas sosial mereka, baik itu melalui pemberian makna atau pemahaman perilaku dikalangan mereka sendiri (Ardianto, 2007:158). Yang menjadi subjek penelitian dalam penelitian ini adalah KPA Kota Padang. Informan penelitian adalah konselor HIV \& AIDS kota Padang yang dipilih secara purposive. Kriteria dari pemilihan informan penelitian adalah pengurus KPA Kota Padang.

\section{HASIL DAN PEMBAHASAN}

Menurut (T. H. Marshall, 1965) kebijakan sosial yang dirumuskan oleh pemerintah memiliki dampak langsung kepada kesejahteraan masyarakat, dalam hal ini kesejahteraan sosial melalui penyediaan pelayanan kesehatan dan sosial Hal tersebut menjadikan suatu pemikiran dari pemerintah dalam melakukan intervensi (keterlibatan) dari peraturan yang berbeda dengan sistem sosial. Menetapkan suatu kebijakan sosial haruslah menunjukkan tata cara bagaimana proses penerapannya dalam menghadapi suatu fenomena sosial, hubungan sosial pemerintah dalam mendistribusikan penghasilan dalam suatu masyarakat. Pada artikel ini mengelaborasi bagaimana perencanaan sosial dan pola komunikasi untuk sosialiasi HIV/AIDS di Kota Padang.

\section{Perencanaan Pelayanan Sosial.}

Penggunaan istilah perencanaan sosial yang paling utama ditentukan pada penyediaan pelayanan-pelayanan pokok di bidang sosial, bukan semata-mata berkaitan dengan sifat ekonomisnya. Pelayanan semacam ini adalah jenis pelayanan yang memberikan sumbangan terhadap kesejahteraan sosial (social wellbeing) penduduk pada perkembangan ekonomi itu sendiri.Interpretasi perencanaan sosial semacam ini dapat ditelusuri kembali ke bentuk asalnya yang berkaitan erat dengan perencanaan pelayanan kesejahteraan sosial khususnya di negara-negara maju. Sejak itulah terbentuk pemahaman perencanaan sosial yang agak sempit ini ditingkatkan guna mencakup pelayanan-pelayanan sosial lainnya, seperti misalnya : pelayanan di bidang pendidikan dan kesehatan, perumahan, pengadaan air bersih, dan penyediaan sarana-sarana rekreasi.Walaupun pelayanan HIV/AIDS tidak mempunyai dampak langsung terhadap perkembangan ekonomi klien, namun layanan yang dilakukan KPA adalah berupa pelayanan sosial untuk mencegah kemiskinan akibat gangguan kesehatan.Hasil wawancara dengan Edo sebagai Monev KPA menjelaskan bahwa tanggung jawab perencanaan sosial sepenuhnya ada di tangan pemerintah dalam hal ini Kementerian Sosial, KPA hanya menjalankan program yang sudah ditetapkan oleh pemerintah.Pada 
konteks ini KPA (konselor) adalah agen yang menjalankan struktur yang sudah dibuat oleh pemerintah.

Pada tahap perencanaan pelaksanaan sudah ditetapkan sumber daya yang akan digerakkan, antara lain tenaga, dana dan fasilitas. Strategi yang sudah dilakukan meliputi:

1. Penguatan jejaring layanan dengan melibatkan semua penyedia layanan.

Di Kota Padang sentra konselor dan tes VCT ada di 22 Puskesmas, Rumah Sakit M Djamil, Rumah Sakit Yos Sudarso. Di rumah sakit dan puskesmas yang menjadi konselor adalah dokter dan perawat yang mendapatkan tugas tambahan sebagai konselor. Konselor merupakan bentukan oleh Dinas Kesehatan dan kemudian dilatih oleh Dinas Kesehatan. Data dari KPA Kota Padang (2018) menunjukkan ada 60 konselor dari berbagai latar belakang dan profesi. Berikut tabel di bawah ini menunjukkan fasilitas yang sudah disediakan pemerintah untuk sentra konselor dan tes VCT.

Tabel

Jumlah Fasilitas Kesehatan Menurut Kecamatan di Kota Padang, 2016

\begin{tabular}{|l|l|c|c|}
\hline \multicolumn{1}{|c|}{$\begin{array}{c}\text { Kecamatan } \\
\text { Subdistrict) }\end{array}$} & $\begin{array}{c}\text { Puskesmas } \\
\text { (Public Health Center) }\end{array}$ & $\begin{array}{c}\text { RumahSakit } \\
\text { (Hospital) }\end{array}$ \\
\hline 1 & Bungus TelukKabung & 1 & - \\
\hline 2 & LubukKilangan & 1 & - \\
\hline 3 & LubukBegalung & 2 & - \\
\hline 4 & Padang Selatan & 3 & 2 \\
\hline 5 & Padang Timur & 1 & - \\
\hline 6 & Padang Barat & 1 & - \\
\hline 7 & Padang Utara & 3 & - \\
\hline 8 & Nanggalo & 2 & - \\
\hline 9 & Kuranji & 3 & - \\
\hline 10 & Pauh & 1 & - \\
\hline 11 & Koto Tangah & 4 & 2 \\
\hline & Padang & 22 & - \\
\hline
\end{tabular}

Sumber: BPS: Kota Padang dalam Angka (2017)

2. Memberdayakan ODHA dan masyarakat sebagai penjangkau untuk upaya pencegahan, perawatan, dukungan, pengobatan dan upaya kegiatan lainnya. Beberapa kegiatan yang dilakukan KPA untuk melibatkan masyarakat dan ODHA sebagai penjangkau diantaranya melalui intervensi individu, yakni dengan cara melakukan pendekatan dengan calon penjangkau baru di sebuah komunitas. Diharapkan penjangkau yang berasal dari komunitas yang sama akan bisa melakukan persuasi lebih baik kepada teman-temannya untuk melakukan tes VCT. Keberadaan penjangkau juga memudahkan KPA untuk melakukan kampanye dan sosialisasi tentang kesehatan seksual dan serta informasi pelayanan tes VCT dan konseling. 
3. Meningkatkan dan memperkuat sistem kesehatan dan manajemen program, melalui peningkatan kapasitas program, pengembangan SDM program yang professional, manajemen logistik.

Pada konteks penanggulangan HIV/AIDS perencanaan sosial adalah kegiatan untuk mempersiapkan masa depan masyarakat. Pesatnya penyebaran HIV/AIDS bukan hanya mengancam demografis penduduk namun juga harus menanggung biaya besar penderita HIV/AIDS.Hal ini tentu saja menjadi beban pemerintah, karena suplai obat dan perawatan pasien HIV/AIDS menjadi tanggung jawab pemerintah.Sampai dengan tahun 2016 saja, terdapat 557 penderita AIDS di kota Padang, tentu saja angka tersebut merupakan hasil yang menakutkan mengingat angka 557 adalah yang terdeteksi saja, sedangkan masyarakat yang belum terdeteksi jauh lebih besar dibandingkan angka yang tertera. Perkembangan yang mengkhawatirkan juga disusul oleh kota Bukittinggi, sebagai kota pariwisata angka 214 penderita bisa dikategorikan sangat tinggi mengingat kota ini adalah kota kecil. Kasus penularan masyarakat terjangkit virus HIV \& AIDS sangat mengkhawatirkan karena penularan serta wilayah penyebarannya semakin meluas. Trend jumlah kasus baru HIV \& AIDS di kota ini dari tahun ke tahun mengalami peningkatan. Sejak tahun 2007 sampai akhir 2013 saja, tampak bahwa setiap tahunnya telah terjadi peningkatan kasus baru lebih dari 100 orang.

Dengan memahami fenomena gunung es, penyusunan pola komunikasi akan sangat membantu sosialisasi dan penyebar luasan program kesehatan yang menyangkut HIV/AIDS, hal tersebut tentunya akan membantu suksesnya perencanaan sosial. Pola komunikasi dengan mempertimbangka struktur sosial dan psikologis khalayak akan membuat kita bisa memiliki empati yang baik mengenai keadaan yang dialami khalayak. Kita tidak berbicara kepada khalayak karena kita ingin mengatakan sesuatu kepada mereka, melainkan harus memikirkan apa yang mereka ingin dengar dan ketahui (Windahl, dkk., 1992: 23).

Perencanaan sosial adalah kegiatan preventif, kegiatan yang dilakukan berupa pengarahan-pengarahan bimbingan sosial mengenai cara hidup yang lebih baik. Seperti sosialisasi dampak seks bebas, sosialisasi penggunaan kondom dan sosialisasi tes HIV/AIDS. Tentunya kegiatan yang direncanakan oleh KPA bersifat segmented, artinya disesuaikan dengan audience yang mereka hadapi. Agar program sosialiasi ini berjalan lancar dibutuhkan bukan hanya dukungan dinas yang terkait namun juga unsur masyarakat. Namun, fakta di lapangan seringkali terjadi gesekan antara unsur pemerintah.

\section{Memperhitungkan Skala Prioritas Sosial Dan Mempertimbangkannya Dalam Perencanaan Pembangunan}

Isu penting dalam konteks perencanaan sosial adalah hal-hal yang berkaitan dengan masalah prosedur dan organisasi. Tidak seperti bentuk perencanaan dalam pelayanan sosial, maka jenis sosial perencanaan ini tidak dapat dialokasikan sebegitu mudahnya kedalam suatu jenis depertemen atau kementerian tertentu (Conyers, 1991:26). KPA sebagai lembaga tentu mempunyai acuan dalam prosedur dan organisasi. KPA sendiri adalah lembaga independen namun banyak melakukan koordinasi dengan beberapa instansi. 
Bentuk perencanaan sosial yang tidak tertuju secara langsung pada faktor-faktor sosial dan ekonomi yang mempunyai interaksi sedemikian kompleksnya dalam proses pembangunan, lebih khusus lagi adalah perlunya perhatian yang cukup memadai mengenai pertimbangan dan tujuan sosial. Merefleksikan realisasi bertahap bahwa faktor-faktor sosial harus diperhitungkan dalam setiap program pembangunan dan bahwa pembangunan sosial mempunyai tujuan penting tersendiri. Pada skala nasional perencana sosial akan terlibat dalam beraneka ragam kegiatan. Mereka membantu merumuskan kebijakan-kebijakan sosial seperti misalnya kebijakan untuk menumpas kriminalitas di perkotaan atau mengatasi masalah pengangguran anak putus sekolah, dan persiapan implementasi program.

Program prioritas KPA adalah penanggulangan resiko rendah dan tinggi. KPA melakukan Program Pencegahan melalui transmisi seksual ( PMTS) dan Layanan Alat Suntik Steril (LASSS). Tugas utama KPA memastikan dan memonitoring kegiatan penanggulangan HIV/AIDS apakah sudah ramah komunitas, apakah sudah sesuai dengan budaya masyarakat setempat dan juga membuat usulan program penanggulangan.

KPA merujuk kegiatan komunikasi berdasarkan modul yang dikeluarkan oleh Kementerian Kesehatan (2011). Di Sumatera Barat, kegiatan komunikasi yang dilakukan lebih banyak menggunakan pendekatan komunikasi interpersonal. Dengan pendekatan ini maka konselor diberikan pelatihan VCT guna menunjang program penanggulangan dan penyebaran HIV/AIDS. Dalam membantu ODHA, konselor diharapkan memiliki keterampilan komunikasi antarpribadi yang baik untuk membangun kepercayaan diri klien sehingga tujuan dari aktivitas komunikasi kesehatan dapat tercapai secara efektif.

Penggunaan komunikasi antar pribadi untuk menimbulkan perasaan empati, keakraban dan keterbukaan antara konselor dan individu. Tidak banyak media yang digunakan dalam sosialisasi informasi tentang HIV/ AIDS, KPA lebih memilih untuk melakukan pendekatan secara interpersonal. Penggunaan media memang bisa menjangkau lebih banyak komunitas dan individu, namun masih adanya kecurigaan dan ketidakmengertian masyarakat akan informasi tentang HIV/AIDS bisa memunculkan kontroversi dan pertentangan. Misalnya saja tentang sosialisasi penggunaan kondom, jika tidak dilakukan pendekatan personal atau sosialisasi langsung bisa menimbulkan kontroversi di masyarakat. Penjelasan yang lebih detail dan adanya feed back akan membantu KPA untuk bisa melakukan sosialisasi dengan baik. PAda konteks ini KPA melakukan komunikasi sirkular dimana komunikator dan komunikan melakukan proses komunikasi berdasarkan feed back yang mereka terima.

Edukasi tentang seks menyasar anak-anak sekolah dan mahasiswa di perguruan tinggi.KPA bekerja sama dengan puskesmas melakukan sosialisasi HIV/AIDS dan IMS kepada kelompok beresiko rendah seperti sosialisasi kepada pelajar di lingkungan sekolah. Tujuan dari kegiatan ini adalah untuk memberikan informasi dan pengetahuan kepada siswa/pelajar tentang tentang penyakit HIV/AIDS dan IMS, penularan HIV/AIDS dan faktor yang berisiko tertularnya serta upaya pencegahan. Pada kelompok yang rentan beresiko, agar tidak menjadi kelompok beresiko maka sedini mungkin diberi pemahaman tentang HIV/AIDS sebagai efek dari pergaulan hidup bebas.Selanjutnya KPA melakukan sosialisasi penggunaan kondom. Pada kelompok yang beresiko program yang dibuat adalah harm reduction, yakni mengurangi resiko gaya hidup seks yang mereka jalankan.KPA pernah melakukan pembinaan dan sosialisasi pada kelompok beresiko yakni seperti sopir-sopir, tukang pangkas dan 
salon.Program yang dilakukan KPA salah satunya adalah edukasi seks dan penggunaan kondom.

Seringkali masyarakat berpandangan negative terhadap sosialisasi penanggulangan HIV/AIDS yang dilakukan oleh KPA.Salah satunya program pembagian kondom dan pembagian jarun suntik.Program tersebut dianggap melegalisasi seks bebas dan penggunaan narkoba. Frame atau cara berpikir yang berbeda tentang bagaimana menangani penanganan penyakit ini lah yang harus dilakukan dialog dan diskusi agar setiap organisasi bisa menjalankan fungsi masing-masing. Di satu sisi tokoh agama berbicara atas dasar moral dan agama, pada pihak lain KPA berbicara dalam konteks harm reduction, yakni bagaimana mengurangi resiko terutama pada kelompok beresiko. Penyakit HIV/AIDS adalah penyakit menular karenanya perlu dilokalisir agar virus ini tidak menular kepada kelompok yang lebih besar.

Stigma negatif yang dilekatkan pada penderita HIV AIDS membuat para penderita ataupun orang yang berpotensi tertular enggan memeriksakan kesehatannya.Dari kasuskasus yang ditangani oleh Komisi Penanggulangan AIDS Kota Padang, banyak yang memeriksakan kesehatannya setelah tertular HIV. Hal seperti yang diungkapkan oleh Eduardo (Edo), selaku tim monitoring dan evaluasi KPA Padang:

"Rata-rata yang banyak kami tanggulangi itu adalah orang-orang yang sudah terlebih dahulu terjangkit HIV. Bahkan, beberapa dari mereka datang dengan kondisi sudah dalam stadium lanjut",

Kelompok yang rentan tertular virus terkadang enggan untuk memeriksakan kondisi kesehatan mereka karena merasa dalam kondisi sehat.Padahal, virus HIV tersebut bisa berdiam diri dalam tubuh orang hingga dalam waktu 10 tahun tanpa terdeteksi. Salah satu cara untuk mengetahuinya adalah dengan mengikuti tes VCT (Voluntary Counseling and Testing).

Melakukan pendekatan kepada calon sukarelawan yang berpotensi tertular HIV AIDS bukanlah pekerjaan mudah. Tertutupnya orang-orang yang rentan tertular ini menjadikan pekerjaan untuk melakukan persuasi dilakukan dengan cara yang tepat. Kalau tidak, justru mereka akan menjauh dari para konselor dan tenaga penjangkau. Masing-masing kelompok beresiko tersebut akan didekati oleh tenaga penjangkau yang punya kedekatan dengan mereka. Kelompok IDU biasanya akan didekati oleh para pemakai narkoba, MSM dan TG biasanya didekati oleh tenaga penjangkau laki-laki. Menurut Edo, hal ini dilakukan karena kelompok beresiko ini biasanya cenderung menolak ajakan orang diluar kelompok mereka. Lapisan kedua yang bertugas mempersuasi kelompok beresiko adalah para konselor. Hampir sama dengan tenaga penjangkau, konselor ini biasanya juga punya spesifikasi dalam menangani kelompok beresiko.

Salah seorang konselor yang menjadi informan peneliti adalah Zulhandi, atau lebih sering dipanggil Ilham, dari KPA Padang.Menurutnya, dia lebih sering menjadi konselor untuk kelompok MSM.Dari kelompok MSM tersebut biasanya dia menangani orang-orang yang sudah dewasa dan bekerja. Lapisan ketiga dalam melakukan persuasi terhadap kelompok beresiko adalah tim monitoring dan evaluasi (monev). Tim monev ini biasanya selalu berkoordinasi dengan konselor dan tenaga penjangkau.

Untuk sebagian kasus, tugasnya adalah menafsirkan aspek-aspek atau implikasi sosial pada suatu proyek yang benar-benar bersifat ekonomis dan meyakinkan bahwa telah diambil langkah-langkah tertentu guna menekan kesenjangan adanya kretakan sosial seminim mungkin serta menyediakan pelayanan sosial yang perlu. Dengan adanya hubungan timbal balik antara faktor sosial dan ekonomi tersebut maka timbullah 
masalah mengenai bagaimana orang dapat mengukur tujuan dan keuntungan sosial yang ada. persoalannya sebenarnya ada dua. Pertama, kriteria apa yang digunakan untuk mengukur perubahan dan keuntungan sosial. Kedua, timbulnya kesulitan dalam mengukur perubahan-perubahan aspek sosial secara nyata.

\section{Jaminan Terhadap Adanya Partisipasi Yang Luas Dalam Perencanaan.}

Ternyata disadari bahwa banyak rencana yang tidak terimplementasikan karena kurangnya perhatian mengenai faktor-faktor sosial yang sangat mempengaruhi proses perencanaan ke dalam dua hal. Pertama, adanya dorongan untuk mendayagunakan perencanaan sosial yang khususnya bertanggung jawab meneliti aspek-aspek sosial pada setiap rencana atau proyek. Kedua, timbulnya pengaruh ke arah partisipasi masyarakat dalam hal perencanaan. Orang-orang yang terkena sasaran suatu proyek haruslah terlibat sebanyak mungkin dalam tahapan perencanaan dengan tujuan agar memberi kepastian mengenai informasi yang mendetail bagi kebutuhan dan kondisi sosial yang mudah diperoleh, dan memberi dorangan masyarakat untuk berpartisipasi dan komitmen yang besar terhadap proyek.

Hal yang menjadi fokus pada pelaksanaan perencanaan sosial adalah keterlibatan masyarakat. Pada negara maju terlihat adanya kenaikan partisipasi masyarakat untuk terlibat dalam proses perencanaan sosial. Keterlibatan ini bisa terlihat dalam aktifnya masyarakat dalam menyuarakan pendapatnya terhadap kebijakan yang akan dibuat pemerintah. Setelah kebijakan tersebut dibuat masyarakat turut aktif membantu pemerintah dan juga melakukan pengawasan.Berbeda dengan masyarakat maju, pada negara berkembang ada kecenderungan untuk tidak terlibat secara aktif dalam perencanaan sosial.Sikap skeptic dan takut menghadapi perubahan menjadi salah satu penyebab.Kurang terlibatnya masyarakat dengan perencanaan sosial juga dikaitkan dengan politik, dimana keran kebebasan berpendapat masih menjadi hambatan untuk masyarakat dalam menyuarakan opininya.

KPA menilai partisipasi masyarakat sangat diharapkan untuk terlibat aktif dalam penanggulangan HIV/AIDS. KPA mempunyai keterbatasan untuk menjangkau kelompok-kelompok yang sebenarnya beresiko tinggi namun karena stigma masyarakat seringkali program KPA menemui hambatan. Hambatan lainnya adalah keengganan klien untuk melakukan tes VCT, hal tersebut disebabkan oleh karena kurangnya pengetahuan dan juga ketakutan bahwa dirinya adalah penderita HIV/AIDS. Menurut Edo, hal tersebut juga menunjukkan epidemic penderita HIV/AIDS di Kota Padang, karena kelompok beresiko tinggi mempunyai gaya hidup seksual aktif dan cenderung berganti-ganti pasangan.

Salah satu kebijakan yang dibuat oleh Kementerian Kesehatan adalah dilibatkannya unsur LSM dan masyarakat. KPA dalam hal ini sudah bekerja sama dengan sebagai lembaga penjangkau. Para penjangkau yang ada di LSM ini lah yang akan melakukan pendekatan pada kelompok beresiko. Kebanyakan penjangkau merupakan bagian dari kelompok beresiko, sehingga mereka mudah untuk melakukan pendekatan persuasi agar anggota kelompoknya mau melakukan tes dan konseling HIV/AIDS. Setelah penjangkau berhasil melakukan pendekatan maka individu tersebut akan melakukan konseling dengan konselor yang sudah ditunjuk. Setelah tahap pre konseling, klien akan melakukan tes HIV. Pada saat melakukan tes, darah akan diambil secukupnya dan pemeriksaan darah ini bisa memakan waktu antara setengah jam sampai satu minggu tergantung metode tes darahnya. Dalam tes HIV, diagnosis didasarkan pada antibodi 
HIV yang ditemukan dalam darah. Tes antibodi HIV dapat dilakukan dengan tes ELISA, Westren Blot ataupun Rapid.

KPA merujuk kegiatan komunikasi berdasarkan modul yang dikeluarkan oleh Kementerian Kesehatan (2011). Di Sumatera Barat, kegiatan komunikasi yang dilakukan lebih banyak menggunakan pendekatan komunikasi interpersonal. Dengan pendekatan ini maka konselor diberikan pelatihan VCT guna menunjang program penanggulangan dan penyebaran HIV/AIDS. Dalam membantu ODHA, konselor diharapkan memiliki keterampilan komunikasi antarpribadi yang baik untuk membangun kepercayaan diri klien sehingga tujuan dari aktivitas komunikasi kesehatan dapat tercapai secara efektif.Penggunaan komunikasi antar pribadi untuk menimbulkan perasaan empati, keakraban dan keterbukaan antara konselor dan individu. Hal ini sesuai dengan pendapat Simon yang menyatakan bahwa "Ada hubungan positif antara kesamaan dengan rasa percaya dan hormat, tetapi hubungannya lemah" (dalam Rakhmat, 2007: 264). Sementara menurut Roger "Orang mudah berempati dan merasakan perasaan orang lain yang dipandangnya sama dengan mereka juga menunjukkan bahwa kesamaan antara komunikator dan komunikate memudahkan terjadinya perubahan pendapat" (dalam Rakhmat, 2007: 262).

Dengan memahami fenomena gunung es ini kita bisa mengatakan bahwa penyusunan PPK akan sangat membantu kesuksesan kampanye komunikasi. Kita tidak akan sembarangan berkampanye dengan cara mengabaikan struktur sosial dan psikologis khalayak. Dalam kampanye sekali-kali jangan menganggap enteng khalayak, melainkan kita mesti memiliki empati yang baik mengenai keadaan yang dialami khalayak. Kita tidak berbicara kepada khalayak karena kita ingin mengatakan sesuatu kepada mereka, melainkan harus memikirkan apa yang mereka ingin dengar dan ketahui (Windahl, dkk., 1992: 23).

\section{PENUTUP}

Di Sumatera Barat, kegiatan komunikasi yang dilakukan lebih banyak menggunakan pendekatan komunikasi interpersonal dengan cara melakukan konselor agar bisa lebih mudah mendekati kelompok yang rentan beresiko. Pola komunikasi membantu KPA untuk bisa merancang perencanaan komunikasi disesuaikan dengan kondisi di lapangan. KPA dituntut untuk bisa menyesuaikan dengan kondisi yang ada agar tujuan mereka tercapai.

Pada dasarnya perencanaan komunikasi yang dibuat oleh KPA Kota Padang merujuk kepada modul yang dibuat oleh Kementerian Kesehatan (2011). Modul ini memberikan data, SOP, arahan tentang bagaimana seorang konselor menghadapi kliennya.

\section{DAFTAR PUSTAKA}

Conyers, D. (1983). Decentralization: The latest fashion in development administration? Public Administration and Development. https//doi.org/10.1002/pad.4230030202

Conyers, D., \& . (1991). An introduction to social planning in the third world.

Glennester, H. (1975). Service Budget and Social Policy: British and American 
experience. Boston: Allen and Unwin.

Jamaludin, A. N. (2015). Sosiologi Perkotaan: Memahami Masyarakat Kota dan Problematikanya. Bandung, CV Pustaka Setia.

Komariah, K., Perbawasari, S., Nugraha, A. R., \& Budiana, H. R. (2013). Pola komunikasi kesehatan dalam pelayanan dan pemberian informasi mengenai penyakit tbc pada puskesmas di kabupaten bogor. Jurnal Kajian Komunikasi, 1(2), 173-185.

Kriyantono, Rachmat. 2012. Teknik Praktis Riset Komunikasi. Jakarta. Kencana Prenada Media.

Liliweri, Alo. (2007). Dasar-dasar komunikasi Antar Budaya. Yogyakarta: Pelajar Pustaka.

Liliweri, Alo. (2013). Dasar-dasar Komunikasi Kesehatan. Yogyakarta: Pustaka Pelajar.

Modul Pelatihan Konseling dan Tes HIV. Direktorat Jenderal Pengendalian dan Penyehatan Lingkungan, Kementerian Kesehatan RI 2011.

Rakhmat, J. (2007). Psikologi Komunikasi. Bandung: Remaja Rosdakarya.

T. H. Marshall. (1965). Social Policy. London: Hutchinson University Library.

Walker, A. (1983). Labour's social plans: The limits of welfare statism *. Critical Social Policy. https//doi.org/10.1177/026101838300300802

Windahl, Sven, Benno H. Signitzer dan Jean T. Olson. 1992. Using Communication Theory An Introduction to Planned Communication. London-California-New Delhi: Sage.

\section{Internet}

BPS Kota Padang (2016). Jumlah Kasus HIV/AIDS. Diperoleh 20 Juli 2018 dari https $/ /$ padangkota.bps.go.id/dynamictable/2017/07/07/91/jumlah-kasus-hiv-aids-imsdbd-diare-tb-dan-malaria-menurut-kecamatan-di-kota-padang-2016-.html 